права человека, $\mathrm{OOH}$.

Horot A. Protection of the Rights of the Specific Categories of Individuals in International Law as a Peculiar Implementation Form of International Human Rights Standards. In today's realities, the problem of human rights is one of the most hotly debated issues. Human rights are one of the most important spheres of inter-state cooperation in the international arena. The article provides a comparative analysis of the protection of the rights of specific categories of persons, such as women and children under international law, and the conformity of their rights with international standards in this field. Most countries have joined their efforts to develop criteria for defining the scope and content of human rights, the ways and means of guaranteeing and protecting them, creating a high-powered supranational system of relevant mechanisms within the UN, the CoE, the EU and the like. The main criterion for evaluating the level of democracy in the modern state is the level of guarantees and protection of human rights, in general, and the rights of women and children as an integral part of international protection, in particular. In view of the above, the countries that share and respect human values in a legal family, ought to implement a number of measures to align domestic human rights and freedoms practices with international standards. International protection of children's rights as a system of international law was formed after the adoption of the UN Charter and the formation of the field of human rights. As part of the UN in 1946, a special children's fund was created UNICEF. The Convention on the Rights of the Child (November 20, 1989) is legally binding for States Parties. The Convention contains special instruments for monitoring the fulfillment by States Parties of their obligations upon accession to the Convention. The Convention on the Rights of the Child also provides for the establishment of a UN Committee on the Rights of the Child to monitor the observance of the rights and freedoms of the child.

Key words: human rights protection, conventions, League of Nations, international standards, human rights, UN.

УДК 327(061.1€С)

DOI https://doi.org/10.32782/2409-4544/2019-2/10

I. Конончук

\title{
Інституційний механізм спільної зовнішньої політики Європейського Союзу
}

У статті проаналізовано акти первинного і вторинного права, що регулюють інституційний механізм спільної зовнішньої політики Європейського Союзу (далі - ЄС). Досліджено правовий статус і повноваження інститутів СС у сфері спільної зовнішньої політики та політики безпеки. Визначаються зміни, що відбулися у сфері спільної зовнішньої політики і політики безпеки ЄС після набуття чинності Лісабонським договором. З'ясовано, що повноваженнями у сфері спільної зовнішньої політики та політики безпеки наділено як головні інститути ЄС (Європейську раду, Європейську комісію, Європейський парламент), так і систему спеціальних органів для реалізації відповідної політики ЄС (Високий представник $\mathrm{CC}$ із зовнішніх справ та політики безпеки, Європейська служба зовнішньої діяльності, Комітет з питань політики і безпеки та робочі групи 3 проблем спільної зовнішньої та безпекової політики). Висвітлено питання розподілу повноважень між інститутами СС. 3'ясовуються особливості функціонування інституційного механізму в рамках співпраці держав-членів у сфері спільної зовнішньої політики та політики безпеки. Інституційний механізм спільної зовнішньої політики СС спрямований на забезпечення цілісності, послідовності й ефективності зовнішньої діяльності ЄС. Лісабонський договір чітко окреслив інституції, які здійснюють спільну зовнішню політику ЄС. Уведення посади Верховного представника Союзу із зовнішніх справ та політики безпеки $є$ найбільш важливим нововведенням у сфері спільної зовнішньої політики й політики безпеки, оскільки він виступає основним суб'єктом підготовки й реалізації всіх заходів ЄС на міжнародній арені.

Ключові слова: спільна зовнішня політики та політика безпеки, Європейський Союз,

(С) Конончук I., 2019 
Верховний представник Союзу із зовнішніх справ та політики безпеки, Європейська служба зовнішньополітичної діяльності, Комітет з питань політики та безпеки.

Постановка наукової проблеми та їі значення. Принципи, інститути та механізми реалізації зовнішньої політики Європейського Союзу визначені в Договорі про ЄС (далі - ДСС) та Договорі про функціонування ЄС (далі - ДФСС). Згідно зі ст. 21 ДСС, у своїх діях на міжнародній арені ЄС керується такими принципами як демократія, верховенство права, універсальність і неподільність прав людини та свобод, повага до людської гідності, рівність і солідарність, дотримання принципів Статуту Об’єднаних Націй та норм міжнародного права.

Реформування інституційного механізму зовнішньої політики ЄС пов'язане $з$ прийняттям Лісабонського договору 2007 р. Становлення інституційного механізму спільної зовнішньої політики й політики безпеки (далі - СЗППБ) ЄС відбувалось упродовж тривалого часу, однак на сьогодні він сформований досить чітко.

Дослідження інституційного механізму зовнішньої політики ЄС є актуальним для України. Після підписання та ратифікації Угоди про асоціацію Україна прагне стати повноправним членом СС, а це вимагає вивчення всіх аспектів функціонування правової системи цього об'єднання, зокрема його інституційно-правової моделі зовнішньої діяльності Союзу.

Аналіз досліджень із цісї проблеми. Вивченню інституційного механізму спільної зовнішньої політики та політики безпеки приділяли увагу такі дослідники, як О. Давиденко, О. Вишняков, Є. Горюнова, О. Гладенко, В. Довгань, В. Копійка, М. Микієвич, В. Муравйов, М. Саракуца, Ю. Слюсаренко, Т. Шинкаренко, І. Яковюк.

Формулювання мети та завдань дослідження. Мета цієї статті - дослідження інституційного механізму спільної зовнішньої політики та політики безпеки.

Виклад основного матеріалу й обгрунтування отриманих результатів дослідження. Аналізуючи інституційну структуру зовнішньої політики $Є С$, у науці європейського права виділяємо різні класифікації інститутів. Одна з них умовно ділить усі інститути, що беруть участь у розробці СЗППБ, на три категорії залежно від здійснюваних повноважень: 1) органи, повноваженнями яких передбачено обговорення й ухвалення політичних рішень; 2) структури, відповідальні за виконання рішень, ухвалених у рамках ЄС, виконання поточних довгострокових завдань і надання консультацій органам, уповноваженим ухвалювати політичні рішення; 3) експертні, консультативні й наглядові органи [2, с. 283].

Повноваженнями у сфері СЗППБ наділені як головні інституції СС (Європейська рада, Рада, Європейська комісія, Європейський парламент), так і ціла система спеціальних органів для реалізації відповідної політики ЄС (Високий представник Союзу з зовнішніх справ та політики безпеки, Європейська служба зовнішньої діяльності, Комітет з питань політики та безпеки й робочі групи 3 проблем СЗППБ).

Спільна зовнішня політика та політика безпеки підпорядковуються спеціальним правилам i процедурам. Ї̈̈̈ визначають та імплементують Європейська рада й Рада, які приймають акти одноголосно, якщо інакше не встановлено ДЄС і ДФЄС. Ухвалення законодавчих актів із цих питань виключається. Свропейська рада визначає стратегічні інтереси $Є С$, фіксує цілі й установлює загальні напрями спільної зовнішньої політики та політики безпеки, уключаючи питання, що мають наслідки у сфері оборони. Європейська рада ухвалює необхідні рішення (ст. 22 ДСС). Рішення Свропейської ради щодо стратегічних інтересів і цілей Союзу стосуються спільної зовнішньої політики й політики безпеки та інших сфер зовнішньополітичної діяльності Союзу. Такі рішення можуть стосуватися відносин Союзу з окремою країною чи регіоном або передбачати тематичний підхід. Вони визначають термін дії й засоби, які мають надаватися Союзом і державами-членами. Європейська рада діє одноголосно за рекомендацією Ради, ухваленою відповідно до умов, передбачених для кожної сфери $[1]$.

Голова Європейської ради, відповідно до ст. 26 ДЄС, може скликати позачергове засідання Європейської ради з метою визначення стратегічних напрямів політики Союзу з огляду на такий розвиток, якщо цього вимагає міжнародна ситуація. Голова Європейської ради, згідно зі ст. 15 ДЄС, представляє Союз у зовнішніх зносинах із питань СЗППБ без шкоди для повноважень Високого представника із зовнішніх справ та політики безпеки.

Згідно зі ст. 26 ДСС, Рада розробляє спільну зовнішню політику й політику безпеки та ухвалює рішення, необхідні для іï визначення й реалізації на основі загальних напрямів і стратегічних настанов, визначених Європейською радою. Так, коли міжнародна ситуація вимагає оперативних дій із боку Союзу, Рада ухвалює відповідні рішення. Вони визначають їхні цілі, межі, засоби, що мають 
бути надані в розпорядження Союзу, а, за необхідності, і їх тривалість та умови реалізації. Рада ухвалює свої рішення, які визначають позицію Союзу з окремих питань географічного чи тематичного характеру, а держави-члени, зі свого боку, повинні забезпечити узгодженість своєї національної політики з позиціями Союзу (статті 28 і 29 Договору про СС).

Кожна держава-член, Високий представник Союзу із зовнішніх справ та політики безпеки самостійно чи за підтримки з боку Комісії можуть вносити на розгляд Ради будь-яке питання стосовно спільної зовнішньої політики й політики безпеки та передавати на її розгляд, відповідно, ініціативи або пропозиції. За потреби швидкого вирішення питання Високий представник за власною ініціативою чи за запитом держави-члена скликає позачергове засідання Ради протягом сорока восьми годин або, за необхідності, за більш короткий термін (ст. 30 ДСС).

На пропозицію Високого представника Союзу із зовнішніх справ та політики безпеки Рада може призначити спеціального представника, якого вона наділяє мандатом стосовно окремих політичних питань. Спеціальний представник виконує свої повноваження під керівництвом Високого представника (ст. 33 ДСС). Крім того, Рада може укладати міжнародні угоди у сфері СЗППБ з іншими державами чи міжнародними організаціями відповідно до загальних правил їх укладання у сфері зовнішніх зносин ЄС [1]. Рада ЄС ухвалює рішення про встановлення правил стосовно захисту фізичних осіб щодо порядку обробки персональних даних державами-членами під час здійснення ними діяльності у сфері СЗППБ (ст. 39 ДСС).

Верховний представник Союзу із зовнішніх справ та політики безпеки призначається Європейською радою кваліфікованою більшістю голосів за погодженням із Головою Європейської комісії та за згодою Європейського парламенту й діє відповідно до мандату Ради, відповідаючи за гармонізацію та координацію зовнішньої діяльності ЄС між Європейською комісією й Радою (ст. 18 ДЄС). Верховний представник Союзу із зовнішніх справ та політики безпеки є відповідальним перед Європейською комісією, Радою і Європейським парламентом. Відповідно до положень ДСС, Голова Європейської комісії може вимагати відставки Верховного представника Союзу із зовнішніх справ та політики безпеки навіть без згоди на це інших комісарів. Свропейський парламент може оголосити вотум недовіри Європейській комісії, наслідком чого буде відставка й Верховного представника Союзу з зовнішніх справ та політики безпеки, який водночас зберігатиме свою посаду в Раді до призначення нового складу Комісії. Верховного представника Союзу із зовнішніх справ і політики безпеки як члена Європейської комісії може бути звільнено відповідно до ст. 247 ДФЄС. Суд ЄС за поданням Ради чи Європейської комісії може відправити у відставкуи будь-кого з комісарів, якщо той перестав відповідати вимогам, необхідним для виконання його обов'язків, чи його визнано винним у вчиненні серйозного проступку [1].

В англомовній літературі під час аналізу організаційно-правового статусу Верховного представника Союзу із зовнішніх справ та політики безпеки часто використовують термін «hat» як синонімічний до лексеми «посада». Потрібно зазначити, що кожна «посада» в цьому контексті уособлює цілий комплекс різноманітних функцій і повноважень. Посада Верховного представника Союзу із зовнішніх справ та політики безпеки характеризується в наукових джерелах як «така, що відіграє подвійну роль» (double-hatted), коли йдеться про концепцію, відповідно до якої зазначена посада поєднує колишні посади Верховного представника Союзу із зовнішніх справ та політики безпеки й Генерального секретаря Ради з посадою єврокомісара із зовнішніх зносин; чи «така, що відіграє потрійну роль» (triple-hatted), коли враховується також те, що він $є$ Головою Ради із зовнішніх зносин [3, с. 414].

Високому представнику Союзу із зовнішніх справ і політики безпеки під час виконання його повноважень допомагає Європейська служба зовнішньополітичної діяльності. Згідно зі ст. 27 ДСС, ця служба співпрацює 3 дипломатичними відомствами держав-членів і включає посадових осіб компетентних служб Генерального секретаріату Ради й Комісії, а також персонал, направлений дипломатичними відомствами держав-членів. Організацію та функціонування Європейської служби зовнішньополітичної діяльності встановлено рішенням Ради ЄС у травні 2010 р. (Рішення Ради ЄС 2010/427) [1; 4]. Високий представник безпосередньо реалізовує зовнішню політику й політику безпеки Союзу та своїми пропозиціями сприяє розробці цієї політики, яку він втілює як уповноважений представник Ради. Ті самі дії він виконує стосовно спільної політики безпеки й оборони. Високий представник головує на засіданнях Ради $\mathrm{CC}$ із зовнішніх зносин і є одним із заступників Голови Європейської комісії. Він забезпечує послідовність зовнішньополітичної діяльності Союзу. У межах Комісії він відповідає за виконання обов'язків, поширених на цей орган у сфері зовнішніх зносин, та за координацію інших аспектів зовнішньополітичної діяльності Союзу (ст. 18 ДСС). 
Певними обсягами компетенції у сфері СЗППБ наділено також Європейську комісію, оскільки Високий представник Союзу із зовнішніх справ та політики безпеки одночасно $є$ заступником Голови Комісії. Свропейська комісія, відповідно до ДСС, веде переговори щодо укладення міжнародних договорів, здійснює представництво ЄС у міждержавних організаціях. Зокрема, у контексті положень стосовно СЗППБ та за підтримки з боку Комісії Високий представник із зовнішніх справ і політики безпеки Союзу й кожна держава-член можуть вносити на розгляд Ради будь-яке питання, яке стосується СЗППБ, і передавати на її розгляд, відповідно, ініціативи та пропозиції.

Згідно з положеннями ДСС, компетенція Європейського парламенту теж у сфері СЗППБ досить обмежена. В ст. 36 ДСС зазначено, що Високий представник Союзу із зовнішніх справ та політики безпеки регулярно консультується з Європейським парламентом із головних аспектів й основоположних пріоритетів СЗППБ, а також інформує його щодо шляхів розвитку цих політик. Високий представник слідкує за тим, щоб думка Європейського парламенту була врахована, а його спеціальні представники можуть залучатися до інформування Європейського парламенту [1].

Згідно зі ст. 24 ДСС Суд ЄС не має юрисдикції щодо положень, які стосуються сфери СЗППБ, за винятком юрисдикції щодо контролю за дотриманням ст. 40 цього Договору та контролю за законністю певних рішень, передбачених у другому абзаці ст. 275 ДФЄС. Реалізація спільної зовнішньої політики й політики безпеки $Є С$ не впливає на застосування процедур і межі повноважень інститутів в інших сферах компетенції ЄС, передбачених відповідними статтями 3-6 ДФЄС, а також установлених для здійснення повноважень Союзу у сфері СЗППБ [1].

Суд $Є С$ має юрисдикцію виносити рішення за позовами фізичних і юридичних осіб щодо актів, адресатами яких вони $\epsilon$, чи які прямо й безпосередньо стосується їх, а також щодо актів, котрі не вимагають заходів 3 імплементації або якими передбачено проти них застосування будь-яких обмежувальних заходів (ст.ст. 263, 275 ДФСС). Згідно зі ст. 218 ДФСС, держава-член, Свропейський парламент, Рада чи Комісія можуть отримати висновок Суду щодо відповідності міжнародних угод договорам СС. У разі негативного висновку Суду ця угода може набути чинності лише тоді, коли до неї будуть внесені зміни чи буде зроблений перегляд договорів.

Комітет з питань політики і безпеки як орган у сфері СЗППБ діє на підставі ст. 38 ДСС та Рішення Ради СС 2001/78 від 22 січня 2001 р. Комітет з питань політики і безпеки, не порушуючи вимог ст. 240 ДФЄС, слідкує за міжнародною ситуацією у сферах стосовно СЗППБ, а також сприяє визначенню політики шляхом підготовки висновків для Ради на іï прохання, на прохання Високого представника Союзу із зовнішніх справ та політики безпеки чи за власною ініціативою. Комітет також стежить за процесом реалізації узгодженої політики, не зменшуючи при цьому повноважень Високого представника (ст. 38 ДЄС). Засідання в межах Комітету відбуваються на рівні високих урядовців держав-членів ЄС у ранзі послів переважно двічі на тиждень [1].

Особливу роль у процесі реалізації СЗППБ відведено державам-членам, які беруть активну участь у формуванні спільної зовнішньої політики, а також займаються іiі реалізацією на національному рівні в тісній співпраці з інституціями ЄС. Тому, як свідчить ст. 32 ДСС, державичлени, перш ніж реалізувати будь-які дії на міжнародній арені або взяти на себе якісь зобов' язання, які можуть вплинути на інтереси Союзу, повинні провести консультації з іншими державами в межах Європейської ради або Ради. За допомогою зближення своїх дій держави-члени забезпечують здатність Союзу обстоювати свої інтереси й цінності на міжнародній арені. Держави-члени повинні демонструвати взаємну солідарність.

Дипломатичні місії держав-членів і делегації ЄC у третіх країнах та при міжнародних організаціях співпрацюють одна з одною й сприяють формулюванню та реалізації спільного підходу.

Висновки. Інституційний механізм спільної зовнішньої політики ЄС спрямований на забезпечення цілісності, послідовності й ефективності зовнішньої діяльності ЄС. Лісабонський договір чітко окреслив інституції, які здійснюють спільну зовнішню політику СС.

Уведення посади Верховного представника Союзу із зовнішніх справ та політики безпеки $€$ найбільш важливим нововведенням у сфері СЗППБ, оскільки він виступає основним суб' єктом підготовки й реалізації всіх заходів Союзу на міжнародній арені - як у рамках СЗППБ, так і за іншими напрямами зовнішньої політики Союзу, уключаючи зовнішньоекономічні зв'язки.

Відповідальними ж за розробку СЗППБ є Свропейська рада й Рада Європейського Союзу. Ці інституції зберігають прерогативи щодо ухвалення в рамках СЗППБ усіх рішень: зі стратегічних питань Європейська рада або стосовно поточних проблем зовнішньої політики Рада ЄЄ. Посилюється роль Європейського парламенту та Європейської комісії в цій сфері. Ухвалення законодавчих актів у сфері СЗППБ прямо виключається. 


\section{Джерела та література}

1. Зібрання актів Свропейського права. Вип. 1: Європейський Союз / упоряд. К. В. Смирнова; за заг. ред. В. І. Муравйова. - Київ: Ред. журн. «Право України», 2013. - 1052 с.

2. Саракуца М. О. Місце Європейської служби зовнішньої діяльності в системі органів Європейського Союзу / М. О. Саракуца // Правова держава. - 2012. - № 15. - С. 283-286.

3. Давиденко О. І. Правовий статус Верховного представника ЄС із закордонних справ та безпекової політики / О. І. Давиденко // Держава і право. Юридичні і політичні науки. - 2013. - Вип. 60. - С. 412418.

4. Council Decision of 26 July 2010 establishing the organisation and functioning of the European External Action Service (2010/427/EU) [Електронний pecypc]. - Режим доступу: https: // https://eeas.europa.eu/sites/eeas/files/eeas_decision_en.pdf.

Конончук И. Институционный механизм внешней политики ЕС. В статье проанализированы акты первичного и вторичного права, регулирующие институционный механизм совместной внешней политики Европейского Союза (далее - ЕС). Исследован правовой статус и полномочия институтов ЕС в сфере общей внешней политики и политики безопасности. Определены изменения, произошедшие в сфере общей внешней политики и политики безопасности ЕС после вступления в силу Лиссабонского договора. Установлено, что полномочиями в сфере общей внешней политики и политики безопасности наделяются как главные институты ЕС (Европейский совет, Совет, Европейская комиссия, Европейский парламент), так и система специальных органов для реализации соответствующей политики ЕС (Высокий представитель Союза по внешним делам и политике безопасности, Европейская служба внешней деятельности, Комитет по вопросам политики и безопасности и рабочие группы по проблемам ОВПБ). Освещены вопросы распределения полномочий между институтами ЕС. Выяснены особенности функционирования институционального механизма в рамках сотрудничества государств-членов в сфере общей внешней политики и политики безопасности. Институциональный механизм общей внешней политики ЕС направлен на обеспечение целостности, последовательности и эффективности внешней деятельности этого политического и экономического обьединения. Лиссабонский договор четко очертил институты, осуществляющие общую внешнюю политику ЕС. Введение должности Верховного представителя Союза по внешним делам и политике безопасности является наиболее важным нововведением в сфере общей внешней политики и политики безопасности, поскольку он выступает основным субъектом подготовки и реализации всех мероприятий ЕС на международной арене.

Ключевые слова: общая внешняя политика и политика безопасности, Европейский Союз, Верховный представитель Союза по внешним делам и политике безопасности, Европейская служба внешнеполитической деятельности, Комитет по вопросам политики и безопасности.

Kononchuk I. Institutional Mechanisms of European Union Foreign Policy. The article analyzes the acts of primary and secondary law governing the institutional mechanism of the joint foreign policy of the European Union (hereinafter - the EU). In the focus of the research are the legal status and powers of the EU institutions in the domain of joint foreign and security policy. The emphasis is laid on the changes in the joint foreign and security policy of the EU, introduced since the Lisbon Treaty came into force. The study has revealed that both the main EU institutions (European Council, Council, European Commission, the European Parliament) and the system of special bodies (High Representative of the Union for Foreign Affairs and Security Policy, European External Action Service, the Political and Security Committee and CFSP Working Groups) are empowered to implement Common Foreign and Security Policy. The key findings of the study elucidate the features of the powers division between EU institutions and the peculiarities of the institutional mechanism functioning in the framework of the Member States cooperation in the field of common foreign and security policy. The institutional mechanism of the common foreign policy of EU is aimed to ensure the integrity, coherence and effectiveness of the external action of EU. The Lisbon Treaty clearly outlined the institutions providing the common foreign policy of EU. The introduction of the High Representative of the Union for Foreign Affairs and Security Policy is the most important innovation in the field of common foreign and security policy, as he is the main actor in the preparation and implementation of all EU measures in the international arena.

Key words: Common Foreign and Security Policy, European Union, High Representative of the Union for Foreign Affairs and Security Policy, European External Action Service, Political and Security Committee. 